\title{
Green Synthesis of Silver Nanoparticles Using Piper nigrum Concoction and its Anticancer Activity against MCF-7 and Hep-2 Cell Lines
}

\author{
Krishnan $\mathbf{V}^{1}$, Bupesh $\mathbf{G}^{2,3 \#}$, Manikandan $\mathrm{E}^{1,2,4,5^{\star}}$, Thanigai Arul $\mathbf{K}^{3 \#}$, Magesh $\mathbf{S}^{3}$, Kalyanaraman $\mathbf{R}^{1 \#}$ and $\mathbf{M a a z a} \mathbf{M}^{4,5}$ \\ ${ }^{1}$ Department of Biotechnology, Vels University, Chennai, India \\ ${ }^{2}$ Central Research Laboratory, Sree Balaji Medical College \& Hospital (SBMCH), Bharath University, Chennai, India \\ ${ }^{3}$ Department of Virology, King Institute of Preventive Medicine \& Research, Guindy, Chennai, India \\ ${ }^{4}$ UNESCO-UNISA Africa Chair in Nanosciences-Nanotechnology, College of Graduate Studies, University of South Africa, Pretoria, South Africa \\ ${ }^{5}$ Nanosciences African Network (NANOAFNET), iThemba LABS-National Research Foundation, Western Cape, South Africa \\ \#Equal Contribution
}

"Corresponding author: Manikandan E, Professor, UNESCO-UNISA Africa Chair in Nanosciences-Nanotechnology, College of Graduate Studies, University of South Africa, Pretoria, South Africa, Tel: +91 9884751467; E-mail: maniphysics@gmail.com

Received date: January 02, 2016; Accepted date: August 03, 2016; Published date: August 11, 2016

Copyright: (@) 2016 Krishnan V, et al. This is an open-access article distributed under the terms of the Creative Commons Attribution License, which permits unrestricted use, distribution, and reproduction in any medium, provided the original author and source are credited.

\begin{abstract}
In the present report, silver nanoparticles were synthesized using Piper nigrum extract for in vitro cytotoxicity efficacy against MCF-7 and Hep-2 cells. The silver nanoparticles (AgNPs) were formed within 20 minutes and preliminarily confirmed by UV-Visible spectroscopy. Further, it was characterized by FT-IR and HR-TEM. The UVVisible analysis showed the strong broad peak located at $441 \mathrm{~nm}$ observed for Ag nanoparticles. TEM images of biosynthesized AgNPs pre-dominantly spherical shape with particle size in the range $20 \mathrm{~nm}$. MTT assays were carried out using various concentrations of silver nanoparticles and Piper nigrum extract ranging from 10 to $100 \mu \mathrm{g} / \mathrm{ml}$. At various concentrations, biosynthesized silver nanoparticles showed a significant cytotoxic effect against both MCF-7 and Hep-2 cells compared to Piper nigrum extract. Therefore, the results reveal excellent applications of green synthesis of silver nanoparticles using Piper nigrum.
\end{abstract}

Keywords: Piper nigrum; Silver nanoparticles; UV-Visible Materials and Methods spectroscopy; FTIR; HR-TEM; Anticancer activity

\section{Introduction}

Recently, metals nanoparticles have received considerable attention of researchers due to their wide unique properties as compared to bulk and possess immense applications in the fields of diagnostics, cell labelings, antimicrobial agents, drug delivery and cancer therapy [1]. Silver nanoparticles have established substantial consideration for different reasons such as valuable antimicrobial agent, reveals low toxicity etc. [2,3]. Plant mediated synthesis is gaining cost effective, economic, eco-friendly and aiding to scale up synthesis of nanoparticles. Biosynthetic processes are an effective way to prepare silver nanoparticles using plants or their extract in a restricted approach due to their dispersion, size and shape [4]. The plant based nanoparticles has enhanced the opportunity of using beneficial nanoparticles in the diagnosis and treatment of human cancers [5].

Piper nigrum (black pepper) is a spicy plant in which the whole plant is medicinally high in nutritional and therapeutic compounds. It possesses many medicinal properties such as antipyretic, antiinflammatory, analgesic, and antimicrobial properties. Here, in the present study the concoction of Piper nigrum was employed to synthesize the silver nanoparticles and characterized by Fourier transform infrared spectroscopy (FTIR), UV-Visible spectroscopy, High resolution transmission electron microscopy (HR-TEM), further for the first time the anticancer activity against MCF-7 and Hep-2 cell lines were carried out.

\section{Materials}

Silver nitrate $\left(\mathrm{AgNO}_{3}\right)$ and MTT were purchased from Hi Media Laboratories Pvt. Ltd. India. The MCF-7 and Hep-2 cancer cell line was purchased from King Institute of Preventive Medicine and Research, Chennai, India.

\section{Preparation of the Piper nigrum hot extract}

Piper nigrum (fruit) were collected from the local market and authenticated. The Piper nigrum (fruit) was finely powdered using morter and pestle. The powder $(20 \mathrm{~g})$ was dissolved in $100 \mathrm{ml}$ of millipore water and the mixture was boiled at $80^{\circ} \mathrm{C}$ for $10 \mathrm{~min}$ and then filtered through syringe filter $(0.45 \mu)$ [6,7].

\section{Synthesis of silver nanoparticles}

Piper nigrum concoction $(10 \mathrm{ml})$ was added to $90 \mathrm{ml}$ of $1 \mathrm{mM}$ silver nitrate solution for the reduction of $\mathrm{Ag}^{+}$ions. Various temperatures such as RT, 40,60 and $80^{\circ} \mathrm{C}$ were maintained using water bath to optimize the synthesis. The solution stirred at $1000 \mathrm{rpm}$ for 10 minutes [8]. The color modulation was observed at various temperatures to ensure the formation of silver nanoparticles. The Piper nigrum seed concoction employed as a reducing and stabilizing agent for $1 \mathrm{mM}$ of silver nitrate $[9,10]$. 
Citation: Krishnan V, Bupesh G, Manikandan E, Thanigai Arul K, Magesh S, et al. (2016) Green Synthesis of Silver Nanoparticles Using Piper nigrum Concoction and its Anticancer Activity against MCF-7 and Hep-2 Cell Lines. J Antimicro 2: 123. doi:10.4172/2472-1212.1000123

Page 2 of 5

\section{Purification of biosynthesized silver nanoparticles}

To remove the excess silver ions, the silver colloids were centrifuged at $10,000 \mathrm{rpm}$ for 15 minutes and washed three times with millipore water. A dried powder of silver nanoparticles was obtained by freezedrying in Alpha Christ 2.0 lyophiliser for further characterization.

\section{Characterization of silver nanoparticles}

The preliminary characterization of silver nanoparticles was carried out using UV-visible spectroscopy $[11,12]$. UV-Vis spectroscopy analysis was done using nanodrop 2000r in a scanning range of 200 $\mathrm{nm}$ to $800 \mathrm{~nm}$. Millipore water was used as a blank. The interactions between protein-silver nanoparticles were analyzed by Fourier transform infrared spectroscopy (FTIR) in the range of 4000 to 400 cm-1 [11]. The TEM images of biosynthesized AgNPs were obtained for size and shape determination using libra $200 \mathrm{HR}$-TEM (m/s Carl Zeiss, Germany) operated at an accelerating voltage $120 \mathrm{kV}$ and 200 $\mathrm{kV}$. The AgNPs sonicated for 5 minutes and a drop of diluted sample placed onto the carbon-coated copper grid. The liquid fraction was allowed to evaporate at room temperature [13].

\section{Cell lines and culture}

Breast cancer cells (MCF-7), and Human Larynx Carcinoma cancer (Hep-2) cell lines were purchased from King Institute of Preventive Medicine and Research, ICMR, Chennai, India. It was cultured in Dulbecco's modified Eagle's medium (DMEM: Hi media Laboratories Mumbai, India), supplemented with $10 \%$ fetal bovine serum and $1 \%$ penicillin/streptomycin (Hi Media Laboratories Mumbai, India). The cell lines were maintained at $5 \% \mathrm{CO}_{2}$ in $\mathrm{CO}_{2}$ incubator [14]. Cultures were examined using an inverted microscope to evaluate the quality of confluency and confirming the absence of bacterial and fungal contaminants [15].

\section{MTT assay}

To determine the cytotoxic effect of silver nanoparticles and Piper nigrum extract, cell viability study was carried out with the MTT reduction assay. MCF-7 and Hep-2 cells were seeded in a 96-well plate at the density of $5 \times 10^{3}$ cells/well. The cells were allowed to attach and grown in 96-well plate for $24 \mathrm{~h}$, in $200 \mu \mathrm{l}$ of DMEM with 10\% FBS [16]. After that the media were removed and replaced with the suspension of various concentrations of silver nanoparticles 10 to $100 \mathrm{mg} / \mathrm{ml}$ (minimum 4 wells were seeded with each concentration) and the cells were incubated for $48 \mathrm{~h} \mathrm{[17].} \mathrm{After} \mathrm{the} \mathrm{addition} \mathrm{of} \mathrm{MTT} \mathrm{(10} \mathrm{ml,} 5 \mathrm{mg}$ / $\mathrm{ml}$ ), the cells were incubated at $37^{\circ} \mathrm{C}$ for another $4 \mathrm{~h}$. The medium was then removed, and $200 \mu \mathrm{l}$ of DMSO added to each well. Optical density (OD) of the formazan product was read at $620 \mathrm{~nm}$ using multi well spectrophotometer $[15,18]$. The results were given as mean of four independent experiments. The OD value was subjected to sort-out percentage of viability by using the following formula,

Percentage of cell viability $=$

\section{Statistical analysis}

The grouped data were statistically evaluated using GRAPHPAD PRISM 6 software. Values are presented as the mean \pm SD of the four replicates of each experiment.

\section{Results and Discussion}

Silver nitrate solution (Figure 1a) is colourless and after adding Piper nigrum plant extract to silver nitrate solution, the colourless silver nitrate solution became dark red in colour (Figure 1b). This confirms that the silver nitrate was reduced and transformed into silver nanoparticles.

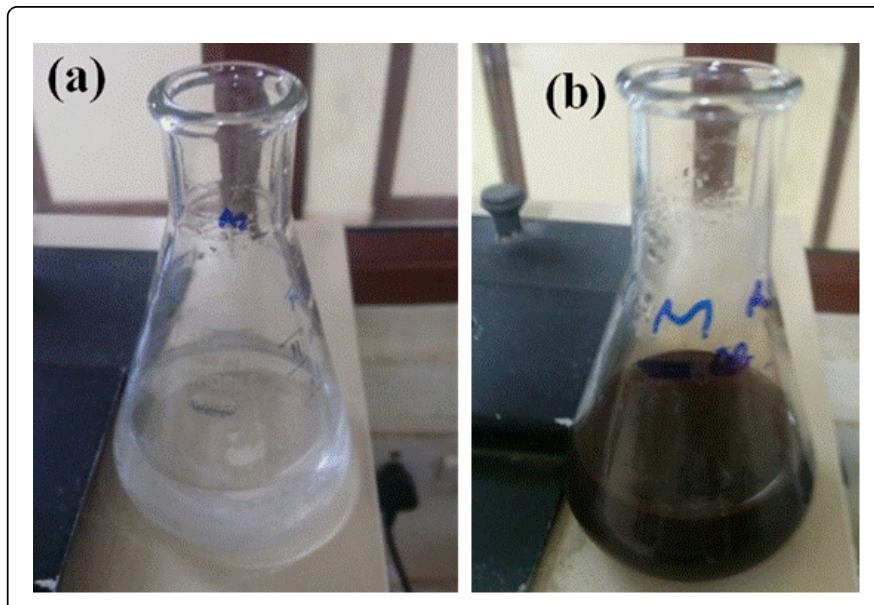

Figure 1: Visual observation of (a) silver nitrate solution (b) biosynthesized silver nanoparticles.

\section{UV-Vis spectral analysis}

UV-Vis spectra of synthesized AgNPs from Piper nigrum extract at different temperature conditions were as shown in the Figure 2. The color change depicts the existence of the formation of silver nanoparticles in the Piper nigrum extract. It shows that the UV-Vis spectra of silver nanoparticle formation at different temperature using Piper nigrum nanoparticle extract (i) Room temperature (RT), (ii) $40^{\circ} \mathrm{C}$, (iii) $60^{\circ} \mathrm{C}$, (iv) $80^{\circ} \mathrm{C}$ in aqueous medium. The surface plasmon resonance bands of colloidal silver for different temperatures were observed in the range 420 to $446 \mathrm{~nm}$. At higher temperature $\left(80^{\circ} \mathrm{C}\right)$, intense SPR band observed compared other samples. The strong SPR broad peak observed at $441 \mathrm{~nm}$ which confirms the formation of silver nanoparticles.

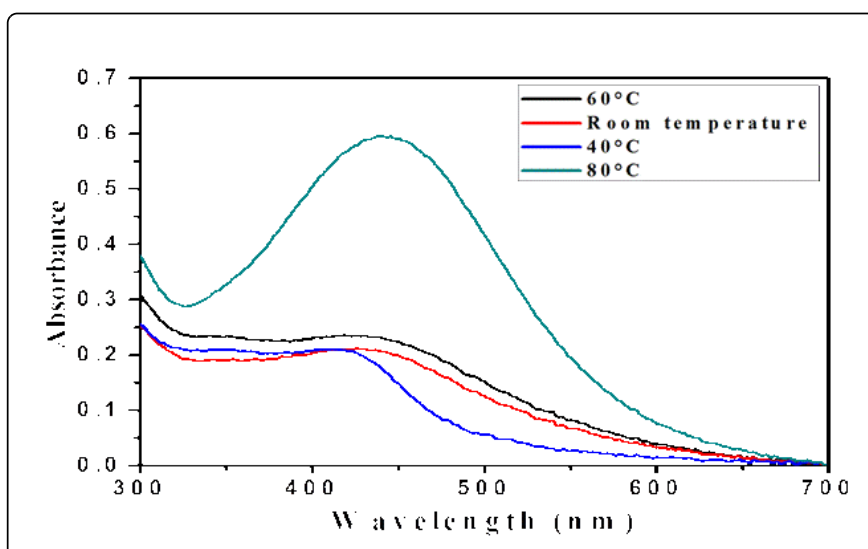

Figure 2: UV-Visible analysis of synthesized AgNPs from Piper nigrum extract at different temperature conditions. 
Citation: Krishnan V, Bupesh G, Manikandan E, Thanigai Arul K, Magesh S, et al. (2016) Green Synthesis of Silver Nanoparticles Using Piper nigrum Concoction and its Anticancer Activity against MCF-7 and Hep-2 Cell Lines. J Antimicro 2: 123. doi:10.4172/2472-1212.1000123

Page 3 of 5

\section{FT-IR analysis}

FTIR spectrum of Piper nigrum is depicted in Figure 3a. The assignments of Piper nigrum observed at $3421 \mathrm{~cm}^{-1}, 2933 \mathrm{~cm}^{-1}, 2388$ $\mathrm{cm}^{-1}, 1632 \mathrm{~cm}^{-1}, 1388 \mathrm{~cm}^{-1}, 1221 \mathrm{~cm}^{-1}, 1021 \mathrm{~cm}^{-1}, 565 \mathrm{~cm}^{-1}$ and 521 $\mathrm{cm}^{-1}$. The band at $3421 \mathrm{~cm}^{-1}$ which corresponds to normal "polymeric" $\mathrm{OH}$ stretching mode. The peak at $2933 \mathrm{~cm}-1$ associated to the methylene $\mathrm{C}-\mathrm{H}$ asymmetric and symmetric stretching mode. The peak at $2388 \mathrm{~cm}^{-1}$ indicates the symmetric stretching of alkanes and the peak at $1632 \mathrm{~cm}^{-1}$ attributed to the $\mathrm{C}=\mathrm{O}$ stretching mode of ketones. The peak at $1388 \mathrm{~cm}^{-1}$ corresponds to the $\mathrm{N}=\mathrm{O}$ stretching of nitro groups of leaf extract. The $1021 \mathrm{~cm}^{-1}$ peak corresponds to the C-C stretch and the aliphatic fluoro compounds C-F stretch. The peaks at $521 \mathrm{~cm}^{-1}$ and $565 \mathrm{~cm}^{-1}$ which are corresponds the aliphatic iodo compounds, C-I stretch, alcohol and $\mathrm{OH}$ out-of-plane bending.

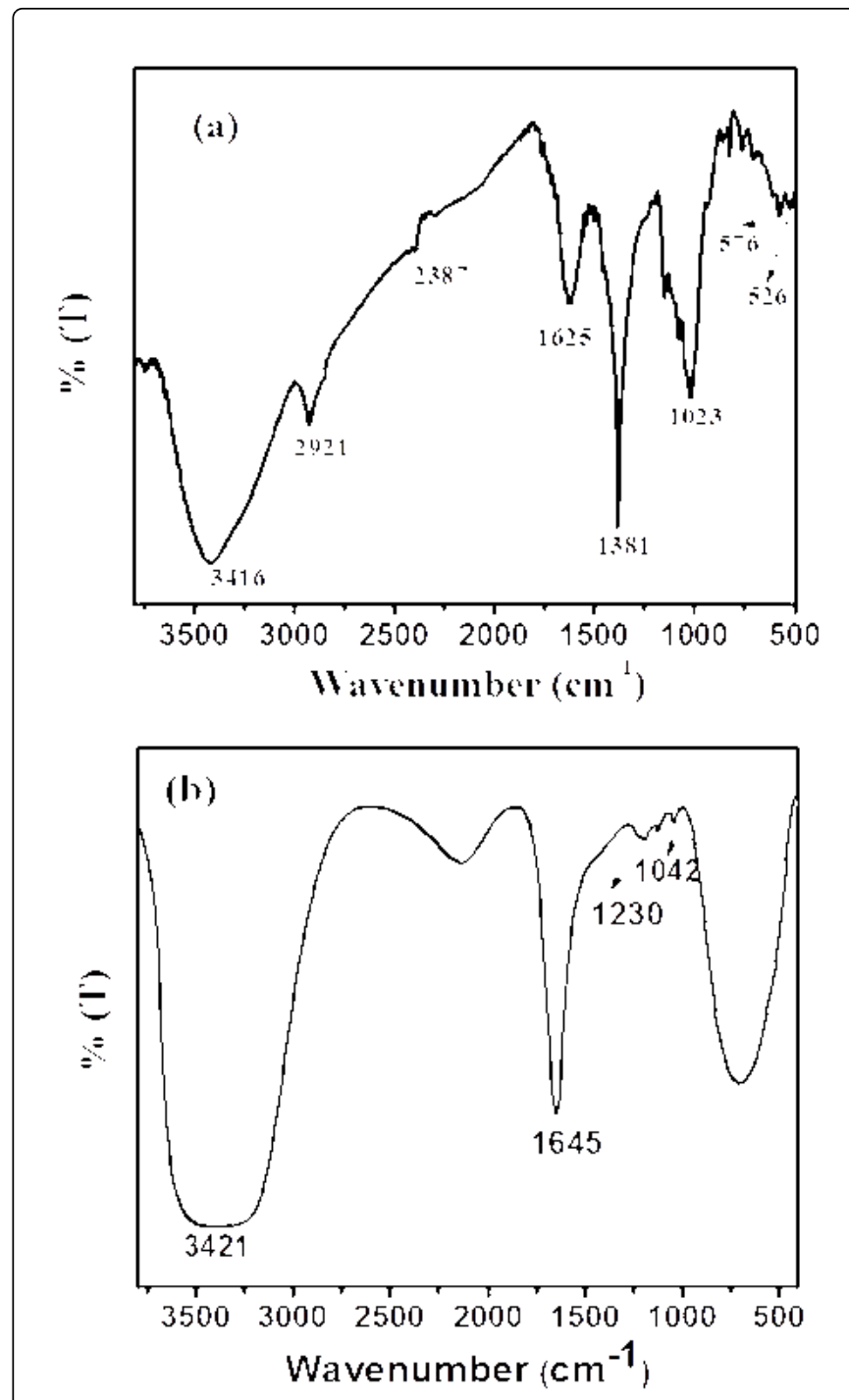

Figure 3: (a) FTIR spectrum of Piper nigrum and (b) FTIR spectrum of biosynthesized silver nanoparticles.

FTIR spectrum of AgNPs Piper nigrum is as shown in the Figure $3 \mathrm{~b}$. Addition of silver nitrate, still, we have the band at $3421 \mathrm{~cm}^{-1}$ which corresponds to "polymeric" $\mathrm{OH}$ stretching mode. An intense peak

observed at $1645 \mathrm{~cm}^{-1}$ attributed to the $\mathrm{C}=\mathrm{O}$ stretching mode of ketone (Figure 3b). The peaks at $1230 \mathrm{~cm}^{-1}$ and $1026 \mathrm{~cm}^{-1}$ which are corresponding to the amine $\mathrm{C}-\mathrm{N}$ stretching, and the $\mathrm{C}-\mathrm{C}$ stretching and the aliphatic fluoro compounds $\mathrm{C}-\mathrm{F}$ stretching respectively present in the AgNPs and the peaks suppressed in comparison with Piper nigrum. The stretching vibration of nitro group of leaf $\left(1388 \mathrm{~cm}^{-1}\right)$, iodo compounds $\mathrm{OH}$ group out of plane bending $\left(521 \mathrm{~cm}^{-1}, 565 \mathrm{~cm}^{-1}\right)$ are completely suppressed due to the addition of silver nitrate, which means the complete reduction and stabilization of the silver nanoparticles. Here, we confirm the modulated transmittance percentage of ketone, fluoro compounds and amine groups play a vital role for the bioreduction of silver nitrate to silver nanoparticles $[6,10]$.

\section{HRTEM analysis}

HRTEM is a powerful tools to analysis the properties of the materials at the atomic level. HRTEM image of AgNPs is shown in the Figure 4. The particle size of AgNPs is approximately in the range of 20 $\mathrm{nm}$ to $40 \mathrm{~nm}$. The nanoparticles are embedded in a dense matrix which may be the organic stabilizing components of Piper nigrum extract. The shape of silver nanoparticles is spherical.

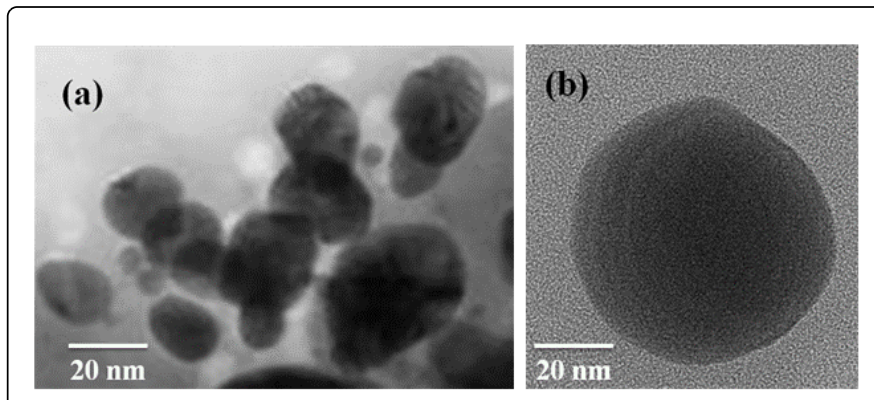

Figure 4: (a) HRTEM image of AgNPs and (b) Magnified portion of AgNps.

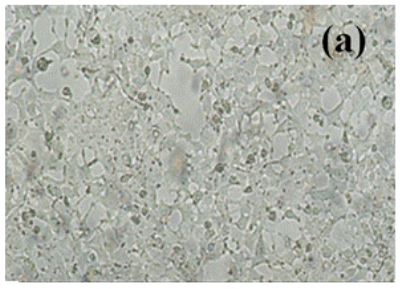

(c)

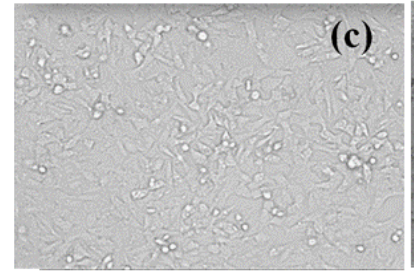

Figure 5: Cytotoxicity of the green synthesized silver nanoparticles against the MCF7. (a) control, (b) cytotoxic and the Hep2 cell line (c) control, (d) cytotoxic. 
Citation: Krishnan V, Bupesh G, Manikandan E, Thanigai Arul K, Magesh S, et al. (2016) Green Synthesis of Silver Nanoparticles Using Piper nigrum Concoction and its Anticancer Activity against MCF-7 and Hep-2 Cell Lines. J Antimicro 2: 123. doi:10.4172/2472-1212.1000123

Page 4 of 5
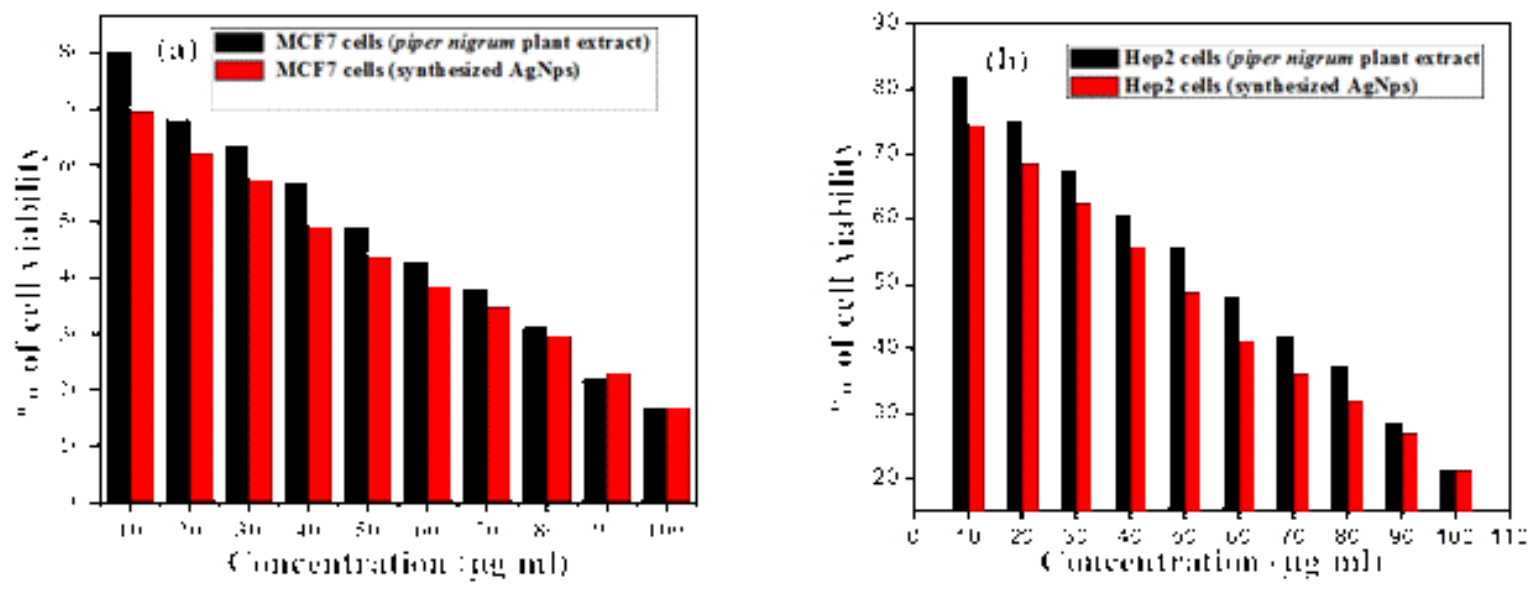

Figure 6: (a) Efficacy of Piper nigrum and biosynthesized AgNps against MCF7 cells at different concentration and (b) Efficacy of Piper nigrum and biosynthesized AgNps against Hep2 cells at different concentration.

\section{Cytotoxicity analysis}

The cytotoxicity of the silver nanoparticle and Piper nigrum extract was studied against the MCF7 (Figures 5a and 5b) and Hep2 cell line by MTT assay (Figures $5 c$ and $5 d$ ). The cytotoxicity effect of cancer cell was studied at different concentration $(10 \mu \mathrm{g}, 20 \mu \mathrm{g}, 30 \mu \mathrm{g}, 40 \mu \mathrm{g}, 50$ $\mu \mathrm{g}, 60 \mu \mathrm{g}, 70 \mu \mathrm{g}, 80 \mu \mathrm{g}, 90 \mu \mathrm{g}, 100 \mu \mathrm{g})$. The inhibitory concentration (IC50) value of the phytomediated AgNPs observed at the concentration of $52 \mu \mathrm{g} / \mathrm{mL}$ against MCF7 cells and Piper nigrum plant extract were observed as $54 \mu \mathrm{g} / \mathrm{ml}$. This study shows that the minimum dose showed good anticancer activity. The Inhibitory Concentration (IC50) value of the phytomediated AgNPs was recorded at $43 \mu \mathrm{g} / \mathrm{ml}$ against Hep-2 cells $[19,20]$. The bar diagram of efficacy of Piper nigrum and biosynthesized AgNps against MCF7 cells at different concentration (Figure 6a). The bar diagram of efficacy of Piper nigrum and biosynthesized AgNps against Hep2 cells at different concentration as shown in the Figure $6 \mathrm{~b}$. In fact, silver nanoparticles may stimulate reactive oxygen species and effect in damage cellular components which lead to cell death [21].

\section{Conclusion}

We report a simple, facile, inexpensive, eco-friendly and green synthesis of silver nanoparticles from the Piper nigrum in aqueous medium without employing manmade chemicals. The UV-Vis spectroscopy and FT-IR analysis is confirmed the preliminary confirmation of the formation of silver nanoparticles. TEM image showed spherical shape with an average particle size of 20-40 nm. The biosynthesized silver nanoparticles and Piper nigrum extract showed promising anticancer activity against breast cancer cells (MCF-7) and human pharynx cancer cell line (Hep-2). From the study, it can be concluded that the silver nanoparticles synthesized using plant possess high anticancer activity against cell lines which further suggested the potential therapeutic use of these nanoparticles.

\section{Acknowledgements}

We are grateful to Dr. G.M. Bhalerao, Scientist-D (Electron Microscope Unit) for HR-TEM measurements, UGC-DAE
Consortium for Scientific Research, kalpakkam node. We also thank Dr. P. Gunasekaran and Dr. K. Kaveri Department of virology, King institute of preventive medicine \& research, for cancer studies.

\section{References}

1. Nel A, Xia T, Madler L, Li N (2006) Toxic potential of materials at the nanolevel. Science 311: 622-627.

2. Seralathan J, Stevenson P, Subramaniam S, Raghavan R, Pemaiah B, et al. (2014) Spectroscopy investigation on chemo-catalytic, free radical scavenging and bactericidal properties of biogenic silver nanoparticles synthesized using Salicornia brachiata aqueous extract. Spectrochim Acta A Mol Biomol Spectrosc 118: 349-355.

3. Ahmed KBA, Subramanian S, Sivasubramanian A, Veerappan G, Veerappan A, et al. (2014) Preparation of gold nanoparticles using Salicornia brachiate plant extract and evaluation of catalytic and antibacterial activity. Spectrochim Acta A Mol Biomol Spectrosc 130: 54-58.

4. Kumar V, Yadav SK (2009) Plant-mediated synthesis of silver and gold nanoparticles and their applications. J Chem Technol Biot 84: 151-157.

5. Sankar R, Karthik A, Prabu A, Karthi S, Shivashangari KS, et al. (2013) Origanum vulgare mediated biosynthesis of silver nanoparticles for its antibacterial and anticancer activity. Colloids Surf B Biointerfaces 108: 80-84.

6. Coates J (2000) Interpretation of Infrared Spectra. John Wiley \& Sons Ltd, Chichester.

7. Geethalakshmi R, Sarada DVL (2012) Gold and silver nanoparticles from Trianthema decandra: synthesis, characterization, and antimicrobial properties. Int J Nanomed 7: 5375-5384.

8. Sulaiman GM, Mohammed WH, Marzoog TR, Al-Amiery AA, Kadhum AA, et al. (2013) Green synthesis, antimicrobial and cytotoxic effects of silver nanoparticles using Eucalyptus chapmaniana leaves extract. Asian Pac J Trop Biomed 3: 58-63.

9. Devi JS, Bhimba BV (2012) Silver nanoparticles: Antibacterial activity against wound isolates \& invitro cytotoxic activity on Human Caucasian colon adenocarcinoma. Asian Pac J Trop Dis 2: S87-S93.

10. Devi JS, Bhimba BV (2012) Anticancer activity of silver nanoparticles synthesised by the seaweed Ulva lactuca invitro. Sci Rep 1: 242-246.

11. Devi JS, Bhimba BV, Ratnam K (2012) Invitro anticancer activity of silver nanoparticles synthesized using the extract of Gelidiella sp. Int J Pharm Pharm Sci 4: 710-715. 
Citation: Krishnan V, Bupesh G, Manikandan E, Thanigai Arul K, Magesh S, et al. (2016) Green Synthesis of Silver Nanoparticles Using Piper nigrum Concoction and its Anticancer Activity against MCF-7 and Hep-2 Cell Lines. J Antimicro 2: 123. doi:10.4172/2472-1212.1000123

Page 5 of 5

12. Renugadevi K, Inbakandan D, Bavanilatha M, Poornima V (2012) Cissus quadrangularis assisted biosynthesis of silver nanoparticles with antimicrobial and anticancer potentials. Int J Pharm Biol Sci 3: 437-445.

13. Ramteke C, Chakrabarti T, Sarangi BK, Pandey RA (2012) Synthesis of silver nanoparticles from the aqueous extract of leaves of Ocimum sanctum for enhanced antibacterial activity. J Chem 2013: 1-7.

14. Prasad TNVKV, Elumalai EK (2011) Biofabrication of Ag nanoparticles using Moringa oleifera leaf extract and their antimicrobial activity. Asian Pac J Trop Biomed 1: 439-442.

15. Satyavani K, Gurudeeban S, Ramanathan T, Balasubramanian T (2011) Biomedical potential of silver nanoparticles synthesized from calli cells of Citrullus colocynthis (L.) Schrad. J Nanobiotechnology 9: 1-8.

16. Krishnaraj C, Muthukumaran P, Ramachandran R, Balakumaran MD, Kalaichelvan PT (2014) Acalypha indica Linn: Biogenic synthesis of silver and gold nanoparticles and their cytotoxic effects against MDA-MB-231, human breast cancer cells. Biotechnol Rep 4: 42-49.
17. Inbathamizh L, Ponnu TM, Mary EJ (2013) In vitro evaluation of antioxidant and anticancer potential of Morinda pubescens synthesized silver nanoparticles. J Pharmacy Research 6: 32-38.

18. Vivek R, Thangam R, Muthuchelian K, Gunasekaran P, Kaveri K, et al. (2012) Green biosynthesis of silver nanoparticles from Annona squamosa leaf extract and its in vitro cytotoxic effect on MCF-7 cells. Process Biochem 47: 2405-2410.

19. Green DR, Reed JC (1998) Mitochondria and apoptosis. Science 281: 1309-1312.

20. Kroemer G, Zamzami N, Susin SA (1997) Mitochondrial control of apoptosis. Immunol Today 18: 44-51.

21. Jacob JP, Finub S, Narayanan A (2012) Synthesis of silver nanoparticles using Piper longum leaf extracts and its cytotoxic activity against Hep-2 cell line. Colloids Surf B Biointerfaces 91: 212-214. 